\title{
English: Key to International Studies and Barrier to Deepened Understanding?
}

\begin{abstract}
Following a discussion of the positive and negative aspects of the use of English in exchange programs, seven hypotheses on the use of the vernacular in academia are analyzed and conclusions drawn, leading to seeing English as one, but not as the only necessary key for international understanding in the academic world.
\end{abstract}

Keywords: academic mobility, aims of language teaching, Campus Europae, communication barriers, Englishes, exchange programs, language interference, lingua franca.

\section{Angielski: Klucz do studiów międzynarodowych i bariera na drodze do pogłębionego zrozumienia}

\begin{abstract}
Abstrakt
W artykule przedstawiono pozytywne i negatywne aspekty posługiwania się językiem angielskim $\mathrm{w}$ programach wymiany międzynarodowej. Postawiono siedem hipotez dotyczących wykorzystywania języka angielskiego jako narzędzia w środowisku akademickim i przeanalizowano skutki jego stosowania. Na tej podstawie postawiono tezę, że stosowanie języka angielskiego jest jednym ze sposobów umożliwiających porozumiewanie się w międzynarodowym środowisku naukowym.

Słowa kluczowe: mobilność akademicka, cele nauczania języków, Campus Europea, bariery komunikacyjne, wersje języka angielskiego, programy wymiany międzynarodowej, interferencja związana $\mathrm{z}$ posługiwaniem się różnymi językami, lingua franca.
\end{abstract}

* University of Hamburg, Germany and European University Foundation Luxembourg. 


\section{Introduction}

In the world about 6000 languages are still spoken, compared to the estimated 20000 around 10000 B.C. ${ }^{1}$ All these languages developed their own ways to look at their environment, to understand it, to classify it and to communicate about it. But today it is a fact that academic publications are by far not written in numbers related to the number of speakers of these 6000 languages. Most are published in English; at most international conferences the working language is English, and even in countries with another official language many conferences use English in order to attract international scholars. English with less than 400 million native speakers outnumbers all other languages with more than 1.1 billion secondary users.

This fact is reflected in the mobility pattern of young academics worldwide. Whether this will turn out to be beneficial or detrimental for the development of science in the long run remains an open question, though the presentation of some facts might help to draw one's own conclusions.

\section{The Role of English in European Student Exchange Programs}

\section{The Erasmus Program}

In Europe in 2012/2013 almost 270000 university students went abroad with "Erasmus", the most successful academic exchange program. Looking at the absolute numbers of movers, most students came from: Spain, Germany, France, Italy, Turkey.

The countries with the greatest tendency towards mobility, i.e. the highest percentage of movers compared to the total student body are: Luxembourg, Liechtenstein, Spain, Lithuania, Latvia.

In the previous years, e.g. in 2011/2012 the picture was almost the same: Spain, France, Germany, Italy, and Poland were the leading countries, when counting the absolute numbers; and when looking at the percentage of the total student population of a country, Luxembourg, Liechtenstein, Spain, Lithuania, Finland and Portugal occupied the top ranks².

The United Kingdom is usually listed in both types of these lists among the three lowest ranking countries. This observation alone could be taken as an indicator that native speakers of English don't feel the need to get acquainted with another linguistic environment.

\footnotetext{
${ }^{1}$ http://home.uni-leipzig.de/muellerg/su/haspelmath.pdf

${ }^{2}$ http://ec.europa.eu/education/library/statistics/ay-12-13/annex-2_en.pdf
} 
Looking at the top receiving countries, the U.K. is listed as number 4 behind Spain, Germany and France in front of Italy, which is number 5. ${ }^{3}$ This could lead to the conclusion that English is not of priority interest to Europe's students. Another measure could be the relation between incoming and outgoing students. There the United Kingdom - together with Denmark, Ireland, Iceland, and Norway - in $2011 / 2012$ belonged to a group with at least almost twice as many inbound students compared to outbound4.

To get an impression of the student flow between the European countries, it might be of interest to visit the page described in foot note 5 , where it is possible to generate a multitude of graphics like the following 5 .

\section{INCOMING AND OUTGOING ERASMUS STUDENT MOBILITY FOR STUDIES IN 2010/2011.}

On mouse over on the band near country name shows total number of outgoing and incoming students of the respective country.

On mouse over on the arc shows total number of students mobility to and from the respective countries.

Color of the arcs obtain the color of the country which has more outgoing students of the respective countries.

Source: European Commission.

Using the template of Mlike Bostock

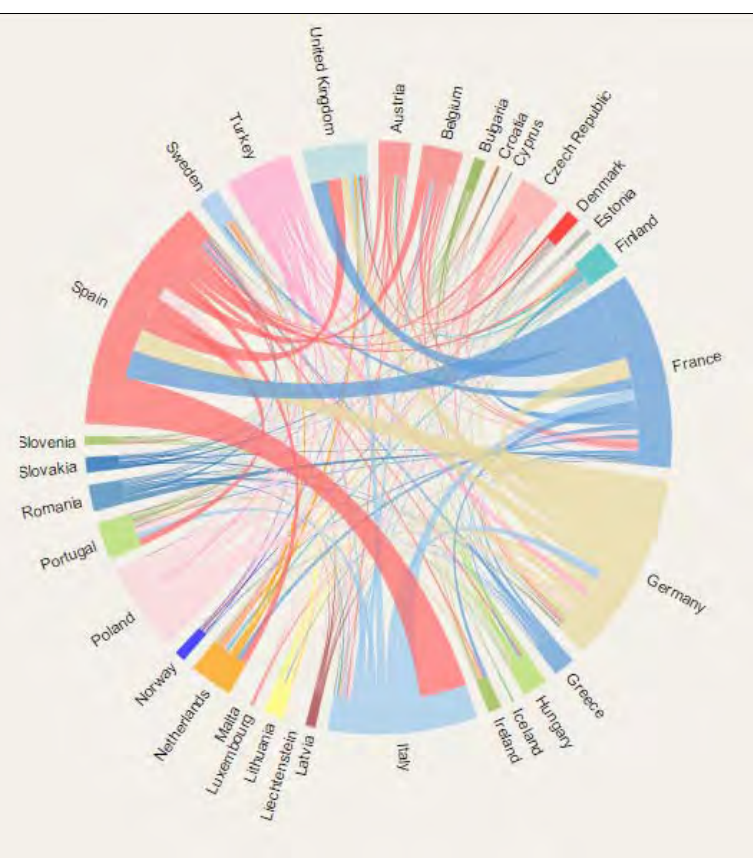

Figure 1. Students' flow between European countries - Erasmus Programme in 2010/2011

Source: http://www.thevisualagency.com/erasmus/An interactive visualization exercise, based on data published by the European Commission on the Erasmus student mobility program in $2010 / 2011$

Nevertheless I dare to claim that "Erasmus" succeeded to a great extent by the use of English as a lingua franca.

\footnotetext{
${ }^{3}$ Ibidem.

${ }^{4}$ http://ec.europa.eu/education/library/reports/erasmus1112_en.pdf Chart 10: Inbound and outbound students in 2011-2012.

${ }^{5}$ http://www.thevisualagency.com/erasmus/An interactive visualization exercise, based on data published by the European Commission on the Erasmus student mobility program in 2010/2011. - See more at: http:// www.thevisualagency.com/wordpress_installation/?portfolio_post_type=erasmus-test\#sthash.HYRk76Il. dpuf
} 


\section{An example: Campus Europae (CE)}

Examples based on data collected in connection with the exchange program "Campus Europae" of the European University Foundation (EUF) ${ }^{6}$ will help to understand this hypothesis.

The idea of EUF-CE is to strengthen and accelerate the development of the European Higher Education Area by establishing examples of concrete cooperation.

Ján Figel', European Commissioner for Education, Training \& Culture from 2004 to 2009, stated that "Campus Europae = Erasmus +", years before the European Commission's exchange programs were restructured under just this heading. This means on the one hand that CE Movers are, with regard to the greatest part of their administrative workflow and to grant allocation, indistinguishable from Erasmus students. So far, preparing a year abroad with Campus Europae is largely similar to going abroad with Erasmus: the same deadlines and procedures are to be observed.

On the other hand there are additional advantages of moving within the CE network of universities like:

- A unique academic degree (a CE- certificate or even e CE degree) which distinguishes the most motivated and talented students;

- Assurance that credits earned abroad under the aegis of the Campus Europae subject committees are recognized without fault or exception;

- An opportunity to acquire the language skills that will allow them to successfully pursue studies abroad through online and intensive language courses - and go abroad a second year and learn a second language!

- The possibility of working abroad by means of study related internships aiming at enhancing European-wide employability ${ }^{7}$.

The program helps students to spend not only one semester but a whole academic year at a university with another language of instruction than at the home university, and one should bear in mind that this in most cases doesn't simply mean "double the time" but usually a stay of 10 months of an academic year compared to three to four month for a semester. During this time they earn credits as at their home university, learn the new language at least reaching level B1 of the Common European Framework, and earning a CE-certificate, issued together with their home university's degree. In case they go out twice to different countries they will even get a CE-diploma.

The use of the English language played an important role for the development of the CE-program, and is since then essential for the functioning of the organization, the management of the program, and the communication within the network

\footnotetext{
${ }^{6}$ For more information cf.: http://uni-foundation.eu/

${ }^{7}$ http://www.campuseuropae.org/en/studying/index.html
} 
and with the political decision makers. Though due to the composition of the network 14 different native languages are used at its member universities - none of which is English! - the main language of communication in all its bodies is English. Native speakers of English are: only three of the 20 members of the board of directors; two of the 82 members of subject committees; none of the 19 delegates forming the student council; one of the 19 Institutional Coordinators, and none of the five persons in the secretariat.

Altogether, only six of the 145 people responsible for the functioning of the European University Foundation have English as their mother tongue, nevertheless English is the main tool for communication - and not German, Russian or Portuguese - the native languages of about 20 people each.

\section{The Importance of English for the Students in Exchange Programs}

Though many students are interested in principle to go abroad, they are full of fears when they are considering applying for an exchange. During more than 40 years of consulting outgoing students I heard over and over again remarks like the following:

I certainly will...

... miss my friend(s)/

... ruin my relationship/

... be totally disappointed/

... not make friends "E/

... see that internship will not meet my expectations/

... get homesick /

... not succeed academically "E"/

... feel lonesome "E"/

... not be able to cope with the language situation "E".

This is the point, where many of their fears lose a lot of the horror, when the applicants are shown and realize that the use of English will help them with most of the envisaged problems. This holds true at least for the items above marked with "E". The students will understand that a good command of English will help them not only to be successful in the selection process, but as well to get started in the new surroundings, to socialize. And they hope that English will allow them to deal successfully with the challenges of academia. 


\section{The limits of usefulness}

\section{The general level of academic aspiration}

English usually proves to be a handy tool during the first weeks of studies abroad, as any lingua franca, as long as students are not sufficiently familiar with the local language. Especially if the host university is offering courses, in which the language of instruction is English, students tend to feel quite at ease. But there seems to be evidence that the academic level in these courses doesn't reach the level of courses taught in the national language of instruction. There has been research by ADAWiS (an association working on the use of German in academic settings) on the understanding of complex issues in parallel courses, where the same content had been taught to one group of German students in English and to another one in German.

\section{Participation in Seminars taught in English}

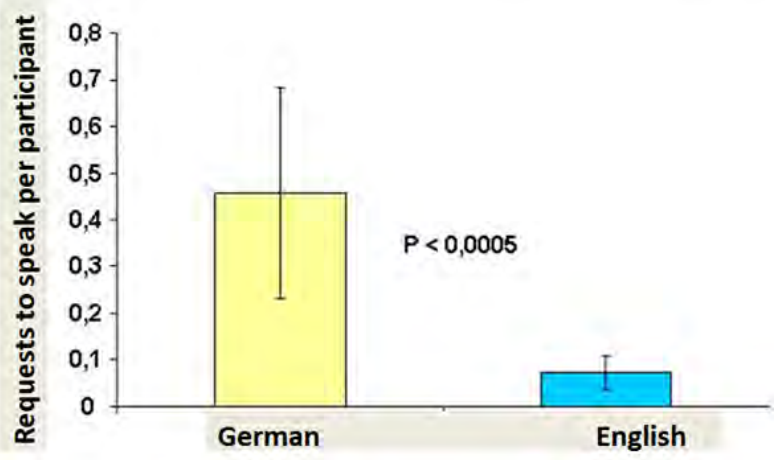

Figure 2. Active participation in seminars thought to German students in English or in German

Source: Mocikat (2008). Text in picture translated from German

In seven courses with about 45 participants each, the contributions to the discussion were counted. In all courses the participants were German scientists with a very good command of English, the topics of the courses were identical. In each of the seminars, the total number of indications to contribute to the discussion was divided by the number of participants. The arithmetical mean of the quotients equalled 0,457 for seminars taught in German ( $s d=0,227 ; n=7$ ) and 0,073 for seminars taught in English ( $\mathrm{sd}=0,036 ; \mathrm{n}=7$ ). The difference is significant with $\mathrm{p}<0,0005$ ( $\mathrm{t}$-Test for unrelated samples). 
Obviously there is a strong reluctance to actively participate in courses not taught in the mother tongue. One might argue that for exchange students the situation is different, as the new language of instruction is even less familiar to them than English. This may be the case - as long as they are in a group of their own. But as soon as students from the host country will join the group, or are even forming the majority, courses taught in English may tend to be less demanding than courses in the national language.

\section{Language interference: vocabulary, socio-linguistic features}

Vocabulary. Exchange program students find themselves, if they are not choosing an English speaking host country, in a three language situation. Usually they notice very soon communicative problems due to "false friends" in the vocabulary, like in these examples with L1 = German and L2 = French:

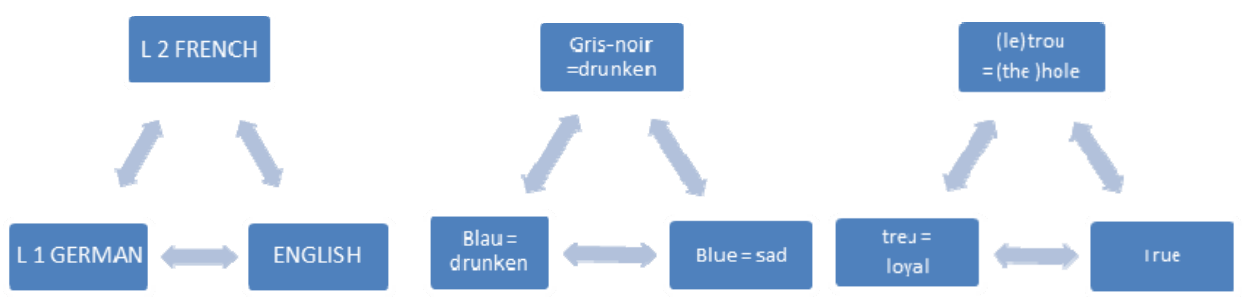

Figure 3. "False friends" in the vocabulary - what might happen when words that sound similar have different meaning

Source: Graph designed by the author

Linguistic problems like these, but as well mental and social blockades and misunderstandings occurring due to an unclear or shifting position between three languages and their functions cause severe problems. Our students found it comparatively easy to overcome these problems when using two languages only Home language and Target language. And this holds true, no matter whether the target language was English OR the host country's language. In a short time they managed to master situations full of linguistic problems:

- What is the appropriate word in this situation?

- How do I express the past tense?

- How do I pronounce/spell xyz?

- ... 
Our students learned to avoid false friends like ${ }^{8}$ :

\begin{tabular}{|c|c|c|c|}
\hline GERMAN & Meaning & $\begin{array}{c}\text { Sounds looks } \\
\text { (almost) like } \\
\text { ENGLISH } \\
\end{array}$ & $\begin{array}{c}\text { German } \\
\text { equivalent }\end{array}$ \\
\hline bekommen & Get & Become & werden \\
\hline brav & $\begin{array}{c}\text { good, well- } \\
\text { behaved }\end{array}$ & Brave & tapfer \\
\hline Chef & Boss & Chef & Küchenchef \\
\hline Gift & Poison & Gift & Geschenk, Gabe \\
\hline Mappe & Folder & Map & (Land) Karte \\
\hline Meinung & opinion, view & Meaning & Bedeutung, Sinn \\
\hline Note & Mark & Note & Notiz, Note \\
\hline spenden & give,donate & Spend & $\begin{array}{l}\text { ausgeben, } \\
\text { verbringen }\end{array}$ \\
\hline treu & Faithful & True & wahr, richtig \\
\hline
\end{tabular}

Figure 4. Examples of "false friends" - comparison of German and English

Source: Examples taken from: Spiropoulou, Paulina-Panajota: Fehler im Tertiärsprachenunterricht

http://www.ecml.at/LinkClick.aspx?fileticket=gCf58WkpvKY=\&tabid=174\&language=en-GB

BUT the students continued finding themselves blocked by mental barriers like:

- I don't dare to talk;

- They will laugh on my funny pronunciation;

- They will judge my paper on its language deficiencies not on its content.

And these blockades did occur NOT ONLY when using the new language BUT ALSO when communicating in English, e.g. because the way of using and pronouncing English in the new country differed from the way they were used to at home. This is pointing to another problematic issue: the multitude of Englishes. We will deal with it later.

Socio-linguistic features. Realizing that there exists a social code often leads to panic stroken reactions! Every sentence, every action is analysed: do the partners mean what they are saying or are they just trying to be polite? And what should be my appropriate reaction? Social blockades of this type and misunderstandings continue to occur even with experienced language users for a longer time.

Here again some things were easy to learn. When it is appropriate to shake hands, bow, give a nod or to combine these elements.

\footnotetext{
${ }^{8}$ Examples taken from: Spiropoulou, Paulina-Panajota.
} 
Some rules were never internalized like the following examples:

\begin{tabular}{|c|c|c|}
\hline $\begin{array}{l}\text { ENGLISH } \\
\text { speaker }\end{array}$ & Meaning & $\begin{array}{c}\text { GERMAN } \\
\text { Hearer } \\
\text { understands/reacts }\end{array}$ \\
\hline Hey, how are you? & Hello! & $\begin{array}{l}\text { Oh, I have a terrible } \\
\text { headache }\end{array}$ \\
\hline Just come on over sometime! & Bye & Is visiting next day \\
\hline I will think about it & NO & He is interested \\
\hline $\begin{array}{l}\text { I wonder if this really is the } \\
\text { best solution }\end{array}$ & NO & ) \\
\hline $\begin{array}{l}\text { I'm wondering if we might } \\
\text { need more time }\end{array}$ & NO & $\begin{array}{l}\text { Hum, it's more or } \\
\text { less O.K. }\end{array}$ \\
\hline $\begin{array}{l}\text { We might want to review } \\
\text { some parts of the project }\end{array}$ & NO & \\
\hline
\end{tabular}

Figure 5. Examples of English phrases that can be misunderstood by a non-English speaking person

Source: Compiled after "USA erklärt” (USA explained):

https://usaerklaert.wordpress.com/2006/09/18/

\section{Problems due to the Multitude of Englishes}

As soon as a third language or another variety of English was involved, chaos was pre-programmed.

English L1 speaker:

(= Asking for positive feedback) Do you like my last essay?

English L2 speaker

from country A

(Assuming to be asked

for an objective statement): Not really/I guess you should have elaborated...

English L1 understands: It is complete nonsense

And might show that $\mathrm{s} / \mathrm{he}$

feels offended/embarrassed

English L2 speaker

from country B observing

the situation:

Is totally lost 
In a continuing 3-language situation, even a stay abroad of 10 months was not enough to overcome these problems. In a finally 2-language situation with a fading out use of English - usually after 4 months - these problems didn't exist any longer. This could lead to two extreme suggestions:

Either: To forget about English in student exchange situations and to try to get along without a lingua franca.

Or: To use English only and to try to abstain from the use of the local language.

This is raising two questions: Is English a reliable tool at all? Is there an alternative?

Is English a reliable tool at all? About 35 years ago I lost all illusions about English as one language worldwide and got the first impression of "Englishes". Being involved in a research project by the International Association for the Evaluation of Educational Achievement ${ }^{9}$, we were about 20 colleagues sitting in a meeting room in Urbana, Illinois, trying to develop tasks and questionnaires for a comparative study on written composition on five continents. In the beginning fifteen school systems were involved ${ }^{10}$, out of which Australia, England, New Zealand, United States, and Wales used English as the language of instruction on all levels of schooling, Nigeria on some levels. During our discussion of how to translate the various national suggestions for writing tasks to be used internationally into English, the delegates from Chile, Germany, Indonesia, Italy, The Netherlands, and Thailand usually agreed after a short exchange of suggestions on what they considered to be the proper translation. Nigeria followed reluctantly. Sweden, Finland and Hungary needed more time for consideration. But Australia, England, New Zealand, the USA, and Wales very often had to continue their discussion about the acceptable translation over lunch. Obviously English is full of traps, I learned. This was my first surprise. And during the coming years, the publication of a book with the title The other Tongue by Braj Kachru from the Indiana University, Bloomington, (1982) and the foundation of the IAWE 11 showed me that I was not fully mislead.

Is there an alternative to English in international settings? But nevertheless, I was convinced that international communication nowadays would not be possible without English - until I was surprised once again, attending the 1990 conference of the Comparative and International Education Society (CIES) in Anaheim, California, with the conference title "Educational Reform in International Perspective". This was the first conference, which scholars from the former Socialist block could

\footnotetext{
${ }^{9}$ The IEA Written Composition Study examined the teaching and learning of written composition in schools in order to identify the associated beliefs and conventions. Cf. http://www.iea.nl/written_composition_study.html

${ }^{10}$ Australia (dropped out later), Chile, England, Finland, Germany (FRG) (Hamburg), Hungary, Indonesia, Italy, Netherlands, New Zealand, Nigeria, Sweden, Thailand, United States, and Wales.

${ }^{11}$ The "International Association for World Englishes Inc. (IAWE)” was founded in May of 1992.
} 
attend, and many newly appointed ministers for education from the successor states of the Soviet Union took the chance as well. In one of the working groups, a participant from one of the countries in the Asian part of the former USSR knowing hardly any English - asked, whether he could put his question in Russian or German. And much to our surprise, about 70 of the 90 participants knew German: besides the German, Austrian and Swiss members, many from the Netherlands and from Scandinavia and in addition all those coming from the eastern countries, for whom German had been over decades the only western language, spoken as well in one of their socialist brother countries - namely the German Democratic Republic. On suggestion of the chair, the work group decided to continue using German as its working language.

Though this was a solution that functioned in this specific setting, replacing one lingua franca by another cannot be considered a solution for our problem. And I am surely not advocating entrusting the German language with this tool. If anything at all, it means that prior to international conferences one should ask with the registration, in which language the participants feel comfortable and try to adjust the structure and the mixture of conference languages accordingly. It is necessary to explore in more detail the relation between English and the vernacular for academic use in different settings.

\section{Seven hypotheses on the use of the vernacular in academia}

\section{Background of the Hypotheses}

In 2005 Ralph Mocikat, Wolfgang Hasse and Hermann. H. Dieter, professors for medicine and natural science in Germany, published seven hypotheses on the use of the vernacular in academia (original version published 18.09.2005), which in a slightly revised version were presented on the occasion of the foundation of the ADAWIS in September 2007.

Based on the fact that the sciences picture reality in hypotheses and theories, which need to be communicable intersubjectively, language does not only prove to be an essential constituent for scientific abstraction but also to form, as many scholars are convinced, the basis for complex thinking in general and thus functions as the unifying element of a communicating society.

At present, the academic world in Germany, as in many countries round the world, is consistently withdrawing from the use of the national language. E.g., more and more scientific journals published in Germany tend to print contributions by German authors in English, the main language at conferences very often is English even when there are no international participants and even lectures and seminars for German speaking students are offered in English regardless of the language 
competence of the professor. This development yields severe detrimental consequences for many countries as places for research und studies ${ }^{12}$.

The seven theses are reflecting general assumptions on the role of the vernacular in relation to a lingua franca and we tried to find out whether some of them apply to the situation of our students in international exchange programs.

\section{Validity of the Hypotheses for English as a Lingua franca}

Thesis 1: On the international level English plays an important role as a medium for communication.

For science and research the international academic exchange of ideas is essential. To ensure communication in a worldwide academic community English serves successfully as lingua franca. There is no doubt that a researcher has to publish his or her results as well in English media and journals.

For student exchange as well - as shown above when describing the structure of Campus Europae - a certain command of English and its use in everyday situations is necessary.

Thesis 2: Using English ONLY within the scientific community of a Non-English speaking society impedes the exchange of ideas.

Only very few of our students are able to use a foreign language with such a degree of differentiation on the level of denotations, connotations, and sentimental values as a native language speaker.

English L2 students very often have problems to present or perceive complex structures. In addition, especially inter- and intradisciplinary approaches are difficult to be understood and used, if both partners use another than the mother tongue as medium of communication.

English L2 professors tend to simplify concepts, when using English as language of instruction. Of course, their mother tongue is more challenging to incoming students, but it offers an advantage which shouldn't be given up without convincing reasons.

Our exchange students reported that they very soon found themselves isolated on an English speaking island with hardly any connection to the host country itself.

Thesis 3: The restriction to a bridge language in the realm of science means a depletion of research possibilities.

It is a well-known fact that every language pictures the view of the world in a specific way, based on the experience of a community throughout history over many generations. Languages as a whole, their vocabulary, semantic and syntactic

\footnotetext{
${ }^{12}$ See http://www.7thesenwissenschaftssprache.de
} 
structures lead to a multitude of ways to perceive reality, which may differ considerably between various speech communities.

This has consequences for science and research. They are usually based on risky and competing hypotheses, independent creative ideas, unconventional approaches, visions and intuitions. Cutting the roots to one's own mother tongue and its explaining power of metaphoric in the academic work means to denounce the work and the substance of the discipline.

In the long run we will do extreme damage to our own scientific productivity if we continue disregarding the multiplicity of our various mother tongues - i.e. the specific structures essential for our thinking and observing - in the process of research and understanding.

One of the desired goals of international exchange, the cross-fertilization of ways of critical thinking, would be endangered by the use of just one language in academic settings.

Thesis 4: The flight to English hampers the future development of the national languages of science and the creativity of international exchange.

The dominance of English leads to an impoverishment of the national languages of science which will turn to be outdated and old fashioned. The abandonment of the national languages makes the further development of scientific terminologies impossible.

In the long run the international academic exchange and the wide spread restriction to British or American English could not only endanger the further development of the national language - might it be a vernacular or one of the other Englishes - but block the possibility to question innovations from abroad on the basis of one's own traditions.

Many Erasmus students, who used English only while being abroad, tend to use the English terms after returning home, without checking the congruency of the term in every aspect.

Thesis 5: The abandonment of the national languages leads to an alienation between science and society.

When asking our exchange students for feedback, many of them reported that the availability of courses taught in English leads to the formation of ghettos for incoming students with little or even no contact to the locals. One might tend to consider the segregation of foreign students (and visiting scholars and scientists) a minor problem, but it is only the tip of the iceberg and an indicator for a possibly dangerous development. If the use of English or any other bridge language is extended to more and more courses for the local students, used as working language in more and more labs, science could find itself in an ivory tower, segregated from the society it is working for and from the support of which its own existence depends. 
As science is an integral part of the society financing it, the willingness to develop the national language for the use in innovative key areas is an important prerequisite to avoid the isolation of the rest of the society. If science does no longer speak the language of the people and cannot communicate its demands in an understandable language to tax-payers and politicians and - perhaps even worse will not notice actual problems and demands of the society, this will lead to a growing disregard of academia in the public attention.

And as far as the interest of international students to go to such a country is concerned, in the long run they will lose interest in mobility, if the language of instruction doesn't help them to get into contact with the world outside academia.

Thesis 6: To give up a national language of science does not result in attracting foreign researchers, scholars and students.

Lectures and seminars given by non-native speakers in English very often seem to be clumsy and un-skilful. The quality of teaching suffers and our students get the impression that professors in their host-country are unable to generate new and innovative ideas, to develop stringent lines of arguments or are weak in university didactics and academic instruction. As a consequence the students don't consider it worthwhile to take the trouble to read the original, native - language publications of these academic teachers.

Foreign students and scholars will lose interest in this country and will prefer to work in an English speaking country to be close to what they consider to be the source of innovation.

Thesis 7: In order to strengthen the role of a country as an interesting place for research and studies a rethinking of the usefulness of the local language as language of science is necessary.

This thesis is describing seven demands, of which the first five are:

1. In national conferences the use of the local language should be the rule.

2. National journals should accept contributions in the country's language with an English summary.

3. The publication of textbooks in the local language should not be stopped for financial reasons.

4. To further develop special scientific terminologies the relevant societies should install competent commissions on nomenclature.

5. Scientific achievement should not only be judged on the basis of English indices but as well on the amount of publications in the local language.

In our context the following two are of special importance:

6. Courses in universities are to be taught in the vernacular language - with the exception of special areas of expertise taught by professors, whose mother tongue is English. 
7. Foreign students have to prove sufficient command of the language of instruction before taking up their studies. The enhancement of the language proficiency has to be an integral part of the basic studies. Guest professors, staying for more than three months, should have a good knowledge of the language of the country as well or start learning it during their stay.

\section{Conclusion}

In history, languages functioned as linguae francae without strangling other languages like a boa constrictor. They were used under very specific conditions: Their use was restricted to certain areas, closely connected to a specific competence of their country of origin, e.g. Italian banking terms, French diplomatic terms, Postclassical Latin for the use in the Roman-Catholic Church. If such a lingua franca was used more widely, it usually wasn't the mother tongue of a still existing group of speakers, e.g. Latin in universities in the Middle Ages and the Early Modern Period.

English nowadays is a necessary key for international understanding. English as lingua franca and a tool for international understanding works best in situations, where there is no interference of English mother-tongue speakers. In these cases, English can play an important role, as a tool, more or less equally unconversant and unfamiliar to all participants in working groups of members with different mothertongues, or as a bridge language - for a limited time only - in order to help students and teachers with different language backgrounds to communicate.

But keep in mind: There is not only ONE key to the world - namely ENGLISH, but as many keys as there are languages in the world - i.e. about 6000! But we should be content if in the European context some more of the 73 European Languages $^{13}$ (or $150^{14}$ ) would be learned and used or at least more of the 24 official languages of the $\mathrm{EU}^{15}$. Let us use as many as possible!

\section{References}

\section{Printed sources:}

Hartmann W. (1993) Vom isolierten Muttersprachunterricht zum Muttersprachunterricht in mehrsprachigen Gesellschaften. Erläuterungen zu sechs Thesen, „Pädagogik und Schule in Ost und West" 41, Heft 1: 12-20.

Kachru Braj B. (1982) The Other Tongue: English Across Cultures, University of Illinois Press.

\footnotetext{
${ }^{13}$ According to http://members.chello.at/heinz.pohl/Sprachen_Europas.htm

${ }^{14}$ According to https://deutschlich.wordpress.com/2009/09/09/wie-viele-sprachen-gibt-es-in-europa/

${ }^{15}$ I still believe that the suggestions I made more than 20 years ago could prove to be a helpful approach. Cf. Hartmann1993.
} 
Mocikat R. (2008) Sprache als heuristisches Werkzeug im naturwissenschaftichen Erkenntnisprozess, „Osnabrücker Beiträge zur Sprachtheorie“ 74: 65-74.

\section{Electronic sources:}

Campus Europae: http://www.campuseuropae.org/en/studying/index.html

European University Foundation: http://uni-foundation.eu/

Languages in Europe: http://members.chello.at/heinz.pohl/Sprachen_Europas.htm

Languages in Europe: https://deutschlich.wordpress.com/2009/09/09/wie-vielesprachen-gibt-es-in-europa/

Mocikat R., Haße W., Dieter H. H. (first publication 28.9.2005) Sieben Thesen zur deutschen Sprache, http://www.7thesenwissenschaftssprache.de [accessed 25.10.2013] also at: http://www.bund-freiheit-der-wissenschaft.de/content/p_sprache_inw.htm [accessed: 7.01.2017].

Sieben Thesen zur deutschen Sprache in der Wissenschaft: http://www. 7thesenwissenschaftssprache.de

Spiropoulou P.P., Fehler im Tertiärsprachenunterricht http://www.ecml.at/LinkClick. aspx?fileticket=gCf58WkpvKY=\&tabid=174\&language $=$ en $-\mathrm{GB}$.

“USA erklärt” (USA explained): https://usaerklaert.wordpress.com/2006/09/18/

http://home.uni-leipzig.de/muellerg/su/haspelmath.pdf 